Rev. Int. Contam. Ambie. 36 (1) 105-114, 2020

DOI: $10.20937 /$ RICA.2020.36.53368

\title{
COPPER IMPROVES THE PRODUCTION OF LACCASE BY Pleurotus sajor-caju WITH ABILITY TO GROW ON EFFLUENTS OF THE CITRUS INDUSTRY
}

El cobre mejora la producción de lacasas en Pleurotus sajor-caju con capacidad para crecer en efluentes de la industria citrícola

\author{
María Isabel FONSECA*, Melisa Antonella MOLINA, Silvana Florencia BENÍTEZ, \\ Marcos Raúl TEJERINA, Juan Ernesto VELÁZQUEZ, \\ Marcela Alejandra SADAÑOSKI and Pedro Darío ZAPATA
}

Laboratorio de Biotecnología Molecular, Instituto de Biotecnología de Misiones - Facultad de Ciencias Exactas, Químicas y Naturales, Universidad Nacional de Misiones. Ruta Nacional 12, kilómetro 7.5, Posadas, Misiones, Argentina, C. P. 3304

*Correponding author: fonsecamariaisabel@yahoo.com.ar

(Received: July 2018; accepted: March 2019)

Key words: biotechnology, green catalysts, white rot fungus

\begin{abstract}
This research is aimed to evaluate the effect of copper on biomass growth, laccase activity and isoenzymes composition of Pleurotus sajor-caju, and its ability to grow on effluents of the citrus industry. The inhibitory effect of copper on growth was evidenced especially after 14 days of culture in the presence of the highest concentration of copper $(1 \mathrm{mM})$ reducing almost three times its growth. The highest enzyme activity was reached at the 10th day of treatment, with $\sim 53 \mathrm{U} / \mathrm{L}$ for the medium without copper and $\sim 121$ and $\sim 68 \mathrm{U} / \mathrm{L}$ for medium supplemented with 0.5 and $1 \mathrm{mM}$, respectively. Laccases in cell-free extracts obtained from culture added with copper showed to be more stable for more time at temperature changes. The optimum temperature for laccase activity increased from 50 to $60^{\circ} \mathrm{C}$ by effect of copper while the optimal $\mathrm{pH}$ was 5 in all experiments. In gels, it was possible to observe two isoenzymes of 65 and $35 \mathrm{kDa}$ whose expression varied according to incubation time. Moreover, the isoenzyme of low molecular weight was induced by the presence of effluent in solid medium. $P$. sajor-caju had the ability to grow on effluents from the citrus industry, showing tolerance and potential for waste treatment, constituting a possible alternative to biodegrade and reduce the contaminating impact of effluents.
\end{abstract}

Palabras clave: biotecnología, catalizadores verdes, hongo de pudrición blanca

\section{RESUMEN}

Esta investigación tuvo como objetivo evaluar el efecto del cobre en el crecimiento de la biomasa, la actividad de lacasas y la composición de isoenzimas de Pleurotus sajor$c a j u$, así como su capacidad para crecer en los efluentes de la industria citrícola. El efecto inhibidor del cobre sobre el crecimiento se evidenció especialmente después de 14 días de cultivo en presencia de la mayor concentración de cobre $(1 \mathrm{mM})$, reduciendo casi tres veces el crecimiento. La actividad enzimática más alta se alcanzó a los 10 días para todos los tratamientos, con $\sim 53 \mathrm{U} / \mathrm{L}$ para el medio sin cobre y $\sim 121 \mathrm{U} / \mathrm{L}$ y $\sim 68 \mathrm{U} / \mathrm{L}$ para los 
medios suplementados con 0.5 y $1 \mathrm{mM}$, respectivamente. Las lacasas en los extractos libres de células obtenidas del cultivo agregado con cobre mostraron ser más estables por más tiempo a los cambios de temperatura. La temperatura óptima para la actividad de lacasas aumentó de 50 a $60{ }^{\circ} \mathrm{C}$ por efecto del cobre, mientras que el pH óptimo fue de 5 en todos los experimentos. En los geles fue posible observar dos isoenzimas de 65 y $35 \mathrm{kDa}$ cuya expresión varió según el tiempo de incubación. Además, la isoenzima de bajo peso molecular fue inducida por la presencia de efluente en medio sólido. P. sajorcaju fue capaz de crecer en el efluente de la industria citrícola, demostrando tolerancia y un potencial para el tratamiento de residuos, constituyendo una posible alternativa para biodegradar y reducir el impacto contaminante de los efluentes.

\section{INTRODUCTION}

White rot fungi (WRF) are the only organisms capable to degrade efficiently recalcitrant wood polymer-lignin (Villalba et al. 2010). This process is due to the fact that they have an oxidative enzymatic system, a group of extracellular ligninolytic enzymes (Fonseca et al. 2010). They usually involve enzymes such as lignin peroxidase (LiP, EC 1.11.1.14), able to oxidize directly non-phenolic units, whilst manganese peroxidase (MnP, EC 1.11.1.13) and laccase (Lac, EC 1.10.3.2) preferentially oxidize phenolic compounds, although non-phenolic units may eventually be degraded in presence of mediators (Fonseca et al. 2015).

Laccases are part of the family of multicopper oxidases (MCOs), which couple the oxidation of substrates to the four-electron reduction of $\mathrm{O}_{2}$ to $\mathrm{H}_{2} \mathrm{O}$. MCOs contain a minimum of four Cu's divided into Type 1 (T1), Type 2 (T2), and binuclear Type 3 (T3) $\mathrm{Cu}$ sites that are distinguished based on unique spectroscopic features. Substrate oxidation occurs near the $\mathrm{T} 1$, and electrons are transferred approximately $13 \AA$ through the protein via the CysHis pathway to the T2/T3 trinuclear copper cluster (TNC), where dioxygen reduction occurs (Jones and Solomon 2015). In search for new, efficient and environmentally benign processes several industries have increased interest in these essentially 'green' catalysts, like laccases that only produce water as by-product concomitant with the reduction of oxygen (Riva 2006). Laccases are able to catalyze the monoelectronic oxidation of various substrates (e.g., phenols, and aromatic or aliphatic amines) to the corresponding radicals, using molecular oxygen as the final electron acceptor (Jeon et al. 2012). Due to the wide range of substrates, laccases have been used to degrade xenobiotic compounds (Balcázar-López et al. 2016), decolorization of Kraft liquor effluents (Fonseca et al. 2014a), detoxification strategies for ethanol production from lignocellulosic biomass
(Moreno et al. 2012), and fabrication of biosensors (Palanisamy et al. 2017).

Laccases have many applications, especially in the area of bioremediation. The non-specific nature of such enzymes allows them to degrade a wide variety of persistent environmental pollutants (Barr and Aust 1994), including dyes (Robinson et al. 2001, Wesenberg et al. 2003), that is why they are involved in many environmental and biotechnological applications. They can be applied to degrade nondesirable toxic compounds, secondary products or waste materials. The published information reflects the significant industrial potential of laccases in the environment (Budolla et al. 2014).

Regulation of laccase expression by metals is widespread in fungi (Piscitelli et al. 2011); thus, laccase gene transcription is often regulated by metal ions (Collins and Dobson 1997).

A range of heavy metals induces the expression of these genes, with regulation operating via a metalregulatory protein which functions both as a metal receptor and as a trans-acting transcription factor (Soden and Dobson 2001). One metal that regulates and also enhances the activity of laccase is copper, which could act at the pre-transcriptional level regulating the beginning of the process (Fonseca et al. 2014b).

The WRF Pleurotus sajor-caju is a member of the oyster mushroom family. This basidiomycete secretes a range of enzymes, most notably laccases, enabled to grow on a variety of different substrates. In Misiones (Argentina), several WRF such us Pleurotus sajor-caju with laccase activity, have been described leading to interesting possibilities for biotechnology as for example in the Kraft liquor decolorization ability on lignin-rich effluents (Fonseca et al. 2015).

The aim of the present work was to evaluate the effect of copper on biomass growth, laccase activity and isoenzymes composition of P. sajor-caju, as well as its ability to grow on effluents of the citrus industry. 


\section{MATERIAL AND METHODS}

\section{Microorganism and maintenance}

The Pleurotus sajor-caju strain used in the present work was previously isolated from the subtropical rainforest of Misiones (Argentina) and was deposited at the Culture Collection of the Faculty of Forestry, Universidad Nacional de Misiones, Argentina. Fungal strain was maintained on malt extract agar (MEA) solid medium $(12.7 \mathrm{~g} / \mathrm{L}$ malt extract, $20 \mathrm{~g} / \mathrm{L}$ agar $)$ plates at $4{ }^{\circ} \mathrm{C}$ and periodically subcultured.

\section{Growth conditions and induction of laccase}

One agar plug $\left(36 \mathrm{~mm}^{2}\right)$ of Pleurotus sajor-caju growing on 5-7-day-old MEA plates was cut and transferred to $50 \mathrm{~mL}$ liquid medium in $250 \mathrm{~mL}$ Erlenmeyer flasks and incubated at $29^{\circ} \mathrm{C}$ in steady-state conditions. Copper addition assays were carried out at concentrations of 0.5 and $1 \mathrm{mM} \mathrm{CuSO}_{4}$ and were added to liquid medium (ME) containing $12.7 \mathrm{~g} / \mathrm{L}$ malt extract and $5 \mathrm{~g} / \mathrm{L}$ corn step liquor to study their effect on laccase production, growth and isoenzyme pattern as described previously (Fonseca et al. 2010). Each experiment included a control without $\mathrm{CuSO}_{4}$. The initial $\mathrm{pH}$ was adjusted to 4.5 with $\mathrm{HCl} 0.1 \mathrm{~N}$ before sterilization. The inoculated medium was incubated for $5,7,10$ or 14 days, then liquid media was separated from the supernatant mycelia by filtering in a Büchner funnel using fiberglass filters $(\mathrm{GF} / \mathrm{C})$ and frozen at -20 ${ }^{\circ} \mathrm{C}$ until use. All experiments were made in triplicate.

\section{Biomass and protein determination}

Biomass dry weight was determined by the difference between the fiberglass filters $(\mathrm{GF} / \mathrm{C})$ weight before and after filtration through a Büchner funnel and subsequent drying at $80{ }^{\circ} \mathrm{C}$ till constant weight (Fonseca et al. 2010).

Protein determinations were done according to the dye-binding method of Bradford (1982), by micro-test using the Bradford technique (BioRad) following manufacturer's instructions with bovine serum albumin as the standard.

\section{Laccase quantification assay}

Laccase activity was assayed as described by Fonseca et al. (2010) at $30^{\circ} \mathrm{C}$ using $5 \mathrm{mM}$ 2,6-dimethoxyphenol (DMP) as substrate in $0.1 \mathrm{M}$ sodium acetate buffer (pH 3.6) (Field et al. 1993). The absorbance increase of the reaction mixture was monitored at $469 \mathrm{~nm}$ $\left(\varepsilon_{469}=27.5 \mathrm{mM} / \mathrm{cm}\right)$ in a Shimadzu UV-3600 spectrophotometer. Enzyme activity was expressed as International Units (U), defined as the amount of enzyme needed to produce $1 \mu \mathrm{mol}$ of product $\mathrm{min}^{-1}$ at $30^{\circ} \mathrm{C}$.

\section{Laccase activity and stability}

Laccase activity in culture supernatants was tested at $\mathrm{pH}$ 3.6-5.6 in $50 \mathrm{mM}$ sodium-acetate buffer using DMP as substrate. After determining the optimum $\mathrm{pH}$, laccase activity was measured in the range 10 to $70^{\circ} \mathrm{C}$. Laccase thermostability was evaluated at optimal $\mathrm{pH}$ by incubating the enzyme preparation at $30,40,50,60$ and $70^{\circ} \mathrm{C}$ and testing its residual activity at several times during $21 \mathrm{~h}$. The effect of $\mathrm{pH}$ on the stability of laccase was evaluated at optimal temperature and determined at $\mathrm{pH}$ 3.6, 4.8 and 5.6,. The remaining activity was determined at several periods of time during $12 \mathrm{~h}$.

\section{Statistics analysis}

Two-way ANOVA with Bonferroni post-test was performed using GraphPad Prism 4.00 for Windows (GraphPad Software, San Diego, CA, USA).

\section{Polyacrylamide gel electrophoresis}

Cell-free filtrates were subjected to native polyacrylamide gel electrophoresis (ND-PAGE, $7.5 \%$ $\mathrm{w} / \mathrm{v})$. After protein separation, gel was incubated in $0.1 \mathrm{M}$ sodium acetate buffer containing $5 \mathrm{mM}$ DMP for laccase activity detection (Fonseca et al. 2010). After a 5-min incubation, the DMP solution was discarded and gel was immediately scanned with Scanner HP Deskjet F300 All-in-One series. In order to determine laccase isoenzymes molecular weight, an electrophoretic separation by SDS-PAGE $(7.5 \% \mathrm{w} / \mathrm{v})$, followed by a subsequent renaturation and detection technique was performed as previously described in literature (Fonseca et al. 2010, 2013) and compared with a molecular weight marker (Amersham ECL Rainbow Marker-Full range, GE Healthcare).

\section{Growth assay and laccase secretion on solid cul- ture with colored effluent}

Growth was studied in Petri dishes (solid media). Mycelial plugs $1 \mathrm{~mm}$ in diameter were inoculated onto plates with MEA medium containing the colored effluent generated in the production of juices and citrus essential oils provided by Cooperativa Citrícola Agroindustrial de Misiones Ltda. (CCAM, Leandro N. Alem) at concentrations of 25, 50 and $100 \%$. MEA without effluent was used as control. The $\mathrm{pH}$ was adjusted to 4 with $0.1 \mathrm{~N} \mathrm{HCl}$ in all cases. Plates were incubated for 10 days at $30^{\circ} \mathrm{C}$ and the diameter of the colony was measured daily.

Fungal growth was modeled by using a logistic equation (Dantigny et al. 2011) modified by Bevilacqua et al. (2016): 
$D=\frac{D_{\max }}{1+e^{k(\tau-t)}}$

where $D$ is the diameter of the fungal colony; $D_{\max }$ the maximum diameter (set to $85 \mathrm{~mm}$, corresponding to the diameter of the plates); $k$ the rate of fungal growth on plate $\left(\mathrm{cm} \mathrm{day}^{-1}\right) ; \tau$ the time needed to attain half of $D_{\max }$ (days), and $t$ the time (days). Adjustment was performed through the software InfoStat 2016p using a least square approach with non-linear regression (Di Rienzo et al. 2016). Fungal growth $\tau$ was standardized as $\Delta \tau=\tau c i t r u s$ effluent $-\tau C$, where $\tau c i t r u s$ effluent and $\tau C$ are the values from medium supplemented with citrus effluent and control culture, respectively. A positive value of $\Delta \tau$ proved growth fungal inhibition in response to citrus effluent.

In parallel, using the same experimental conditions, laccase activity was revealed for which the plate was covered with 1.2 mM ABTS [2,2'-azinobis(3-ethylbenzothiazoline-6-sulphonic acid)] in acetate buffer $\mathrm{pH} 4.5$ and incubated in dark for 20 min; on the other hand, it was also revealed with 5 $\mathrm{mM}$ of DMP in the same buffer. The appearance of green and orange colors in the solid media, respectively, indicated a positive result (Fonseca et al. 2015). At the same time, another assay was carried out to determine the laccase specific activity in plates with effluents. The content of the plates was frozen at $20^{\circ} \mathrm{C}$ for $24 \mathrm{~h}$, then thawed centrifuged $(15 \mathrm{~min}$, $10000 \mathrm{~g}$ ) and the supernatant was used for sowing in SDS-PAGE as previously described.

\section{RESULTS}

\section{Effect of $\mathrm{Cu}^{2+}$ addition on mycelia biomass weight} and protein secretion

In figure 1a, it is possible to observe the effect of $\mathrm{Cu}^{2+}$ addition on mycelial biomass and secreted proteins. The inhibitory effect of copper on $P$. sajorcaju growth was evidenced especially at the 14th day of culture $(p<0.001)$. The growth in presence of the highest concentration $(1 \mathrm{mM})$ of copper reduced almost three times its growth. Copper treatments with $1 \mathrm{mM}$ produced significant protein increases at the 5th day of culture, while treatments with $0.5 \mathrm{mM}$ or without copper did not show differences $(\mathrm{p}<0.05)$ (Fig. 1a).

\section{Effect of $\mathrm{Cu}^{2+}$ addition on laccase activity and enzymatic profile}

In figure 1a, $\mathbf{c}$ it is possible to observe the effect of $\mathrm{Cu}^{2+}$ addition on laccase activity and isoenzymatic patterns. At the 10th day of incubation, laccase activity increased significantly $(\mathrm{p}<0.001)$ in cultures supplemented with $\mathrm{Cu}^{2+}$. This increment was dosedependent and significantly higher with $0.5 \mathrm{mM}$ of $\mathrm{CuSO}_{4}(\mathrm{p}<0.001)$. The highest enzyme activity was reached at the 10th day for all treatments, with $\sim 53 \mathrm{U} / \mathrm{L}$ for the medium without copper and $\sim 121$ and $\sim 68 \mathrm{U} / \mathrm{L}$ for medium supplemented with 0.5 and $1 \mathrm{mM} \mathrm{Cu}$, respectively. The zymogram analysis showed two isoenzymes, one of $65 \mathrm{kDa}$ and another of $35 \mathrm{kDa}(\mathbf{F i g} . \mathbf{1 b}, \mathbf{c})$. On days 5 and 7 it was possible to observe the presence of an enzyme of greater mobility with $35 \mathrm{kDa}$, and on days 10 and 14 two isoenzymes of 35 and $65 \mathrm{kDa}$ were visible.

\section{Laccase activity and stability}

We determined the optimal temperature and $\mathrm{pH}$ for laccase activity in culture supernatants originated in different treatments, as shown in figure 2. In the absence of copper, the optimal temperature was 40-50 ${ }^{\circ} \mathrm{C}$ and in culture supernatants supplemented with 0.5 and $1 \mathrm{mM}$, these enzymes exhibited maximal activity at $50-60{ }^{\circ} \mathrm{C}$. The optimal $\mathrm{pH}$ value for laccase in all treatments was 5 (Fig. 2).

The enzymatic stability of Laccase present in supernatants obtained in the medium with and without copper was also evaluated at different $\mathrm{pH}$ values and temperatures.

Regarding thermostability, laccase activity was kept during $21 \mathrm{~h}$ above $50 \%$ at $30^{\circ} \mathrm{C}$, and for more than $21 \mathrm{~h}$ at $40{ }^{\circ} \mathrm{C}$, while at 50 and $60^{\circ} \mathrm{C}$ the half-life showed double activity in presence of copper, turning down dramatically at $70^{\circ} \mathrm{C}$ (Table I).

The laccase enzyme showed high $\mathrm{pH}$ stability, keeping a constant activity after $12 \mathrm{~h}$ of incubation at $\mathrm{pH} 5$, while half-life was 5 and $7 \mathrm{~h}$ at $\mathrm{pH} 3.6$ and 7 and $10 \mathrm{~h}$ at $\mathrm{pH} 4$ in absence and presence of copper, respectively.

\section{Effect of colored effluent on laccase growth and secretion}

The inhibitory effect in the effluent on $P$. sajorcaju was studied in three concentrations. P. sajor-caju grew up quickly in the medium control $(\tau=6.85$ days) while its growth decreased in presence of $25 \%$ of effluent ( $\tau=2.5$ days) and showed absolute growth inhibition with the addition of 50 and $100 \%$ of effluent.

The presence of effluent in the culture medium at a concentration of $25 \%$ delays four days the fungal growth ( $\Delta \tau=4.35$ days) (Fig. 3 ).

Laccase secretion with greater specific activity was evidenced in the presence of effluents of the 

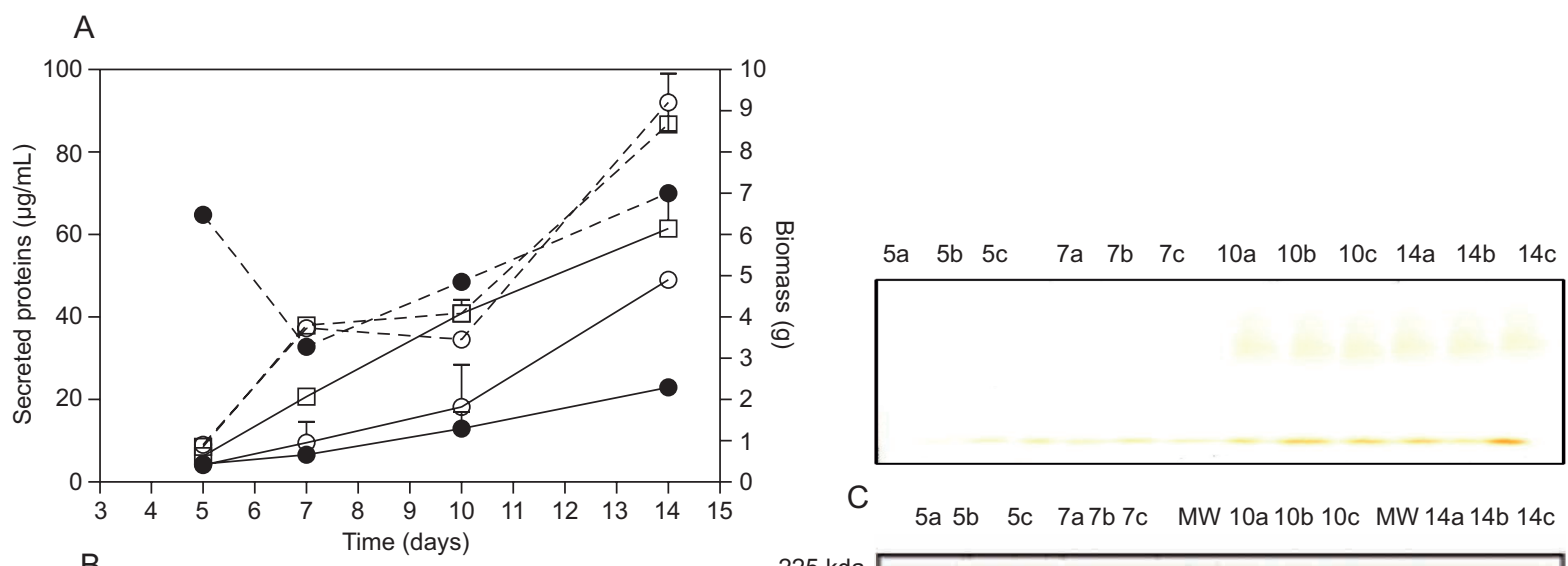

B

C

$5 a$ 5b 5c 7a7b 7c $\quad$ MW 10a 10b 10c $\quad$ MW 14a 14b 14c
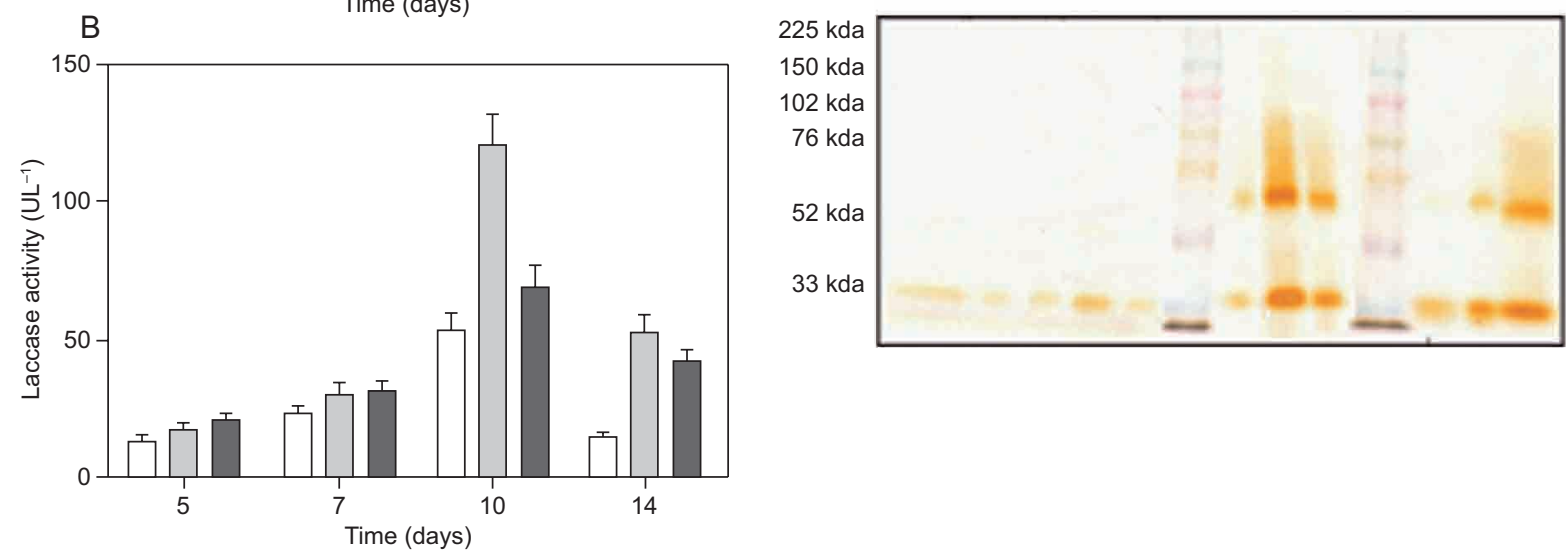

Fig. 1. Effect of $\mathrm{Cu}^{2+}$ addition on mycelial biomass, secreted proteins, laccase activity and isoenzymatic patterns. (a) Effect of $\mathrm{Cu}^{2+}$ addition on mycelial biomass and secreted proteins. Mycelial biomass expressed in $\mathrm{g}(-)$ and secreted proteins expressed in $\mu \mathrm{g} / \mathrm{mL}(--)$ were determined from 5, 7, 10 and 14 days of culture without ( $\square$ ) or with $0.5 \mathrm{mM}(\circ)$ or 1 $\mathrm{mM}(\bullet)$ of $\mathrm{CuSO}_{4}$ for . sajor-caju. Data are presented as the average from duplicate experiments. (b) $\mathrm{Effect}_{\text {of }} \mathrm{Cu}^{2+}$ addition on laccase activity of $P$. sajor-caju with $0.5 \mathrm{mM}$ (grey bar) and $1 \mathrm{mM}$ (black bar) and control without copper (white bar). Below each graph the zymogram from laccase supernatants is shown. $20 \mu \mathrm{g}$ protein/well were seeded for each condition tested, using gels at $7.5 \% \mathrm{w} / \mathrm{v}$ non-denaturing polyacrylamide gel electrophoresis (ND-PAGE) revealed with 2,6-dimethoxyphenol (DMP). Control (a) samples without the compound. Numbers indicate the day of cultivation and letters the compounds concentration (a) without copper, (b) with $0.5 \mathrm{mM}$ and (c) with $1 \mathrm{mM}$. Data are representative of three independent experiments. (c) Molecular weight (MW) estimation (by sodium dodecyl sulfate polyacrylamide gel electrophoresis [SDS-PAGE]) of laccase isoenzymes. Twenty micrograms of protein from cell-free extracts were obtained in different days of cultivation in $\mathrm{ME}$ without or with $0.5 \mathrm{mM}$ or $1 \mathrm{mM}$ of $\mathrm{CuSO}_{4}$, analyzed with $7.5 \%$ SDS-PAGE gels and incubated with DMP. Numbers indicate the days of cultivation and letters the $\mathrm{CuSO}_{4}$ concentration: (a) 0 , (b) 0.5 and (c) $1 \mathrm{mM}$
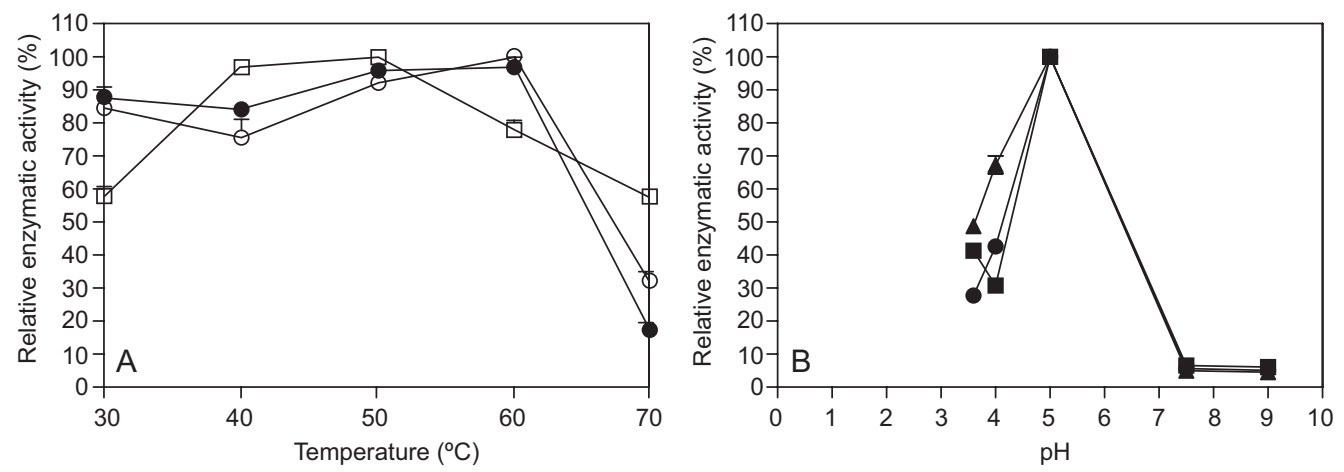

Fig. 2. Effects of (a) temperature and (b) $\mathrm{pH}$ on laccase activity of $P$. sajor-caju. Cell-free extracts were obtained from the liquid medium (ME) $(12.7 \mathrm{~g} / \mathrm{L}$ malt extract and $5 \mathrm{~g} / \mathrm{L}$ corn step liquor without [] or with [०] $0.5 \mathrm{mM}$ or $1 \mathrm{mM}[\bullet]$ of $\left.\mathrm{CuSO}_{4}\right)$ 
TABLE I. HALF-LIFE OF LACCASE ACTIVITY IN CULTURE SUPERNATANTS INCUBATED AT DIFFERENT TEMPERATURES (AT OPTIMAL $\mathrm{pH}$ ) AND pHss (AT OPTIMAL TEMPERATURE)

\begin{tabular}{lccc}
\hline $\begin{array}{l}\text { Evaluated } \\
\text { characteristic }\end{array}$ & $\begin{array}{c}\text { Without } \\
\mathrm{Cu}^{+2}\end{array}$ & $\begin{array}{c}\text { With } 0.5 \mathrm{mM} \\
\text { of } \mathrm{Cu}^{+2}\end{array}$ & $\begin{array}{c}\text { With } 1 \mathrm{mM} \\
\text { of } \mathrm{Cu}^{+2}\end{array}$ \\
\hline Half-life at pH 3.6 & $5 \mathrm{~h}$ & $7 \mathrm{~h}$ & $7 \mathrm{~h}$ \\
Half-life at pH 4 & $7 \mathrm{~h}$ & $10 \mathrm{~h}$ & $10 \mathrm{~h}$ \\
Half-life at pH 5 & $>12 \mathrm{~h}$ & $>12 \mathrm{~h}$ & $>12 \mathrm{~h}$ \\
Half-life at 30 to $40{ }^{\circ} \mathrm{C}$ & $>21 \mathrm{~h}$ & $>21 \mathrm{~h}$ & $>21 \mathrm{~h}$ \\
Half-life at 50 to $60^{\circ} \mathrm{C}$ & $2 \mathrm{~h}$ & $4 \mathrm{~h}$ & $4 \mathrm{~h}$ \\
Half-life at $70{ }^{\circ} \mathrm{C}$ & $10 \mathrm{~min}$ & $30 \mathrm{~min}$ & $30 \mathrm{~min}$ \\
\hline
\end{tabular}

Note: The half-life of laccase activity is expressed as the time necessary for the enzymatic activity to be reduced by $50 \%$

citrus industry with $3.452 \mathrm{U} / \mathrm{mg}$; while in the absence of the effluent it was $1.5 \mathrm{U} / \mathrm{mg}$ at day 10 of cultivation. The zimogram evaluation is shown in figure 4. In the absence of effluent, the enzyme of $65 \mathrm{kDa}$ was evidenced, while in the presence of effluent the expression of another isoenzyme of lower molecular weight (35 kDa) was induced (Fig. 4).
The fact that $P$. sajor-caju grew up in the presence of effluent indicates its potential use for bioremediation of citrus industries effluents.

\section{DISCUSSION}

Copper is an essential heavy metal for fungal growth, a micronutrient and also an activator of several enzymes in fungal and pigment synthesis. However, $\mathrm{CuSO}_{4}$ at high concentrations turned into an inhibitor for mycelial growth in P. sajor-caju, which was also observed in P. otreatus by Patel et al. (2009) due the toxic effect when it is added in excess. Regarding the proteins secreted, the highest concentration of copper tested only on the 5th day showed a greater amount of protein. These results were opposed to those reported for P. ostreatus by Palmieri et al. (2000), where a decrease of protein secretion was observed.

Almost all species of WRF were reported to produce laccase to a varying degree (Hatakka 1994). After screening several WRF strains, $P$. sajor-caju evidenced laccase activity and also showed high phenol oxidation rates, indicating the significance of
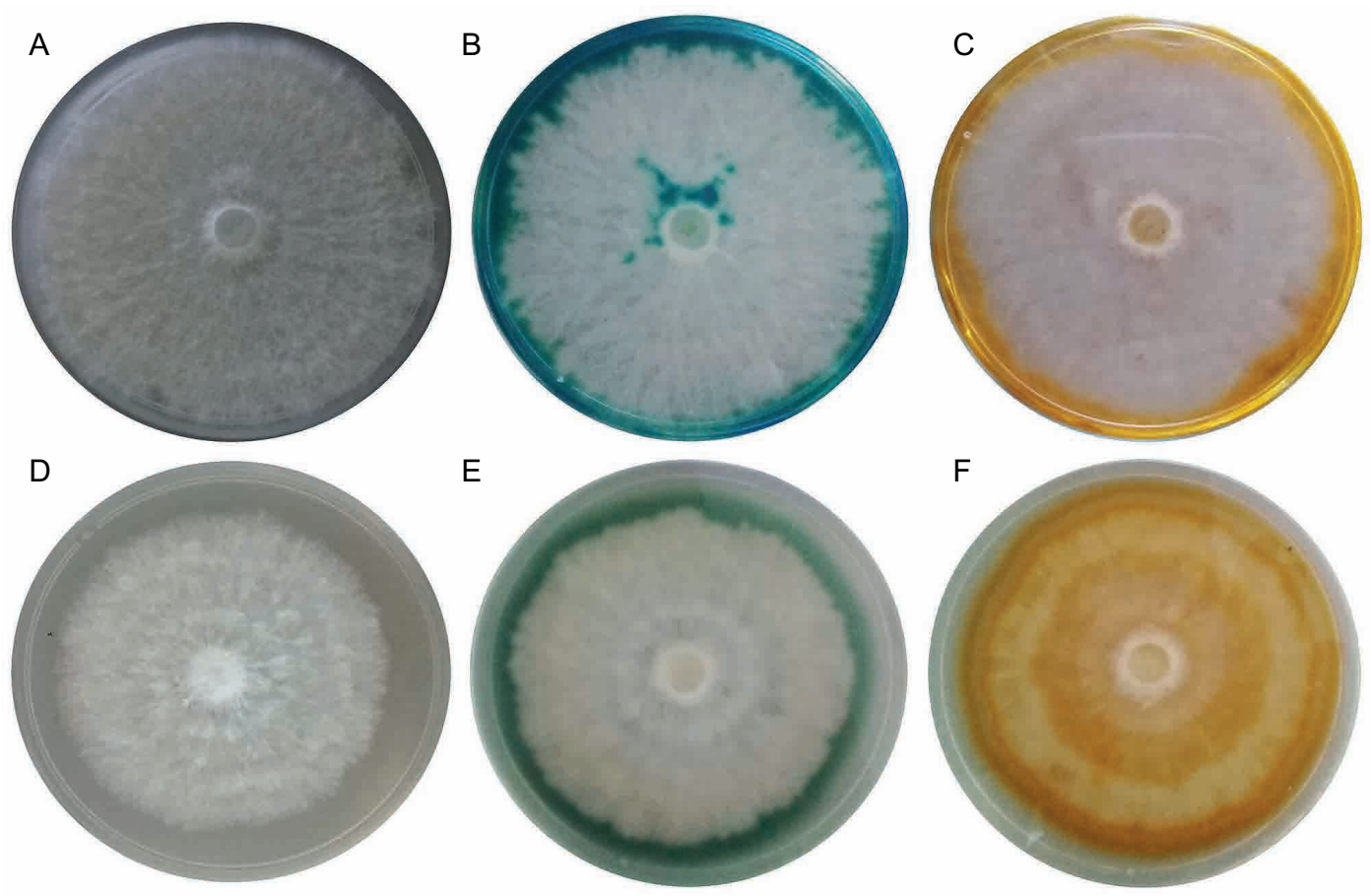

Fig. 3. Macroscopic view of the growth and detection of laccase enzyme activities on solid media at the 10th day of cultivation. (a) Mycelial appearance on agar solid medium containing $12.7 \mathrm{~g} / \mathrm{L}$ malt extract and $20 \mathrm{~g} / \mathrm{L}$ (MEA) and (d) MEA with $25 \%$ effluent from the citrus industry. (b, c) Laccase detection on MEA and (e, f) MEA with $25 \%$ effluent from the citrus industry with (b, e) [2,2'-azino-bis(3-ethylbenzothiazoline6-sulphonic acid)] or (c, f) 2,6-dimethoxyphenol (C and F) 


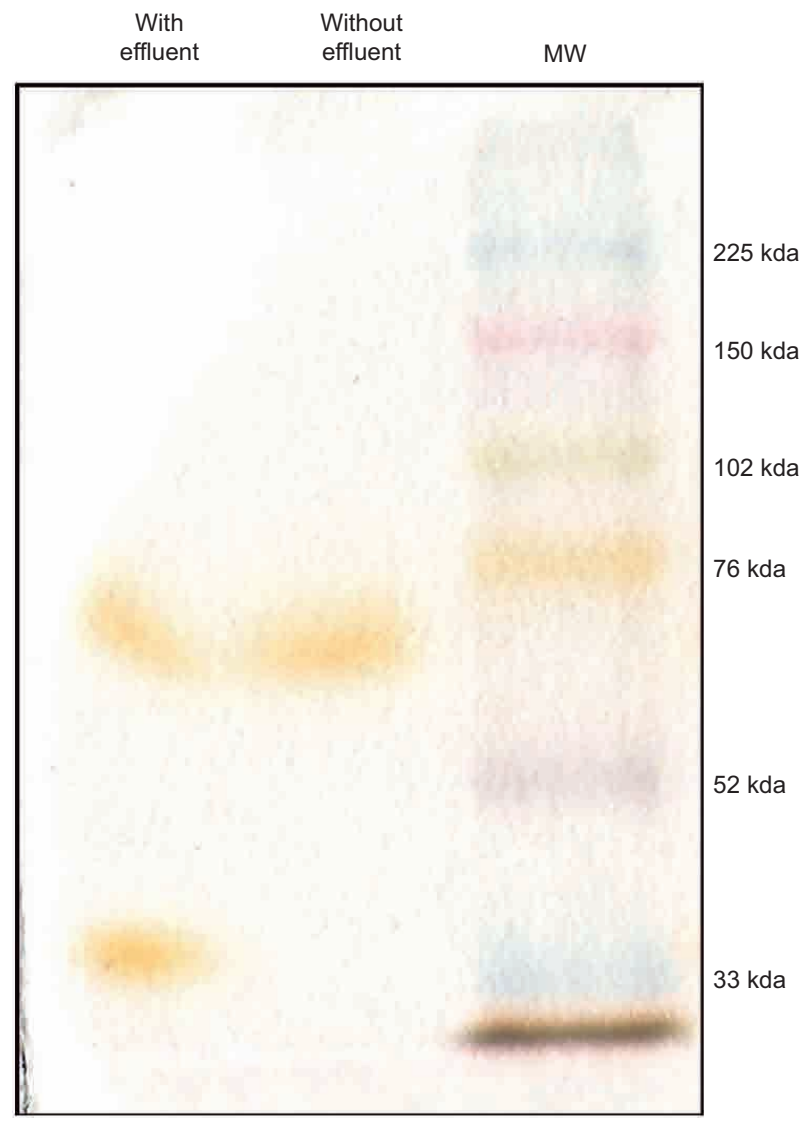

Fig. 4. Molecular weight (MW) estimation by sodium dodecyl sulfate polyacrylamide gel electrophoresis (SDS-PAGE) of laccase isoenzymes. Twenty micrograms of protein from cell-free extracts were obtained from the 10th day of cultivation in liquid medium containing $12.7 \mathrm{~g} / \mathrm{L}$ malt extract and $5 \mathrm{~g} / \mathrm{L}$ corn step liquor without or $25 \%$ effluent from the citrus industry, analyzed with $7.5 \%$ SDS-PAGE gels and incubated with 2,6-dimethoxyphenol

additional approach to evaluate a potential biotechnological application (Fonseca et al. 2015).

The inducing effect of copper on laccase activity of $P$. sajor-caju was both dose- and time-dependent, as it was also observed by Zhu et al. (2016) regarding $P$. ostreatus. Our results indicate that smaller amounts of $\mathrm{Cu}^{2+}$ gave better results in shorter times.

Laccases are generally extracellular monomeric glycoproteins with molecular weights ranging from 60 to $80 \mathrm{kDa}$, and up to $30 \%$ of their molecular weight can be made up of carbohydrates (Thurston 1994, Giardina et al. 2010). Two isoenzymes could be detected, one in the expected range of $65 \mathrm{kDa}$ and another of lower molecular weight, $35 \mathrm{kDa}$. Other authors, such as Wang and $\mathrm{Ng}$ (2006), have also described a $34 \mathrm{kDa}$ laccase for Pleurotus eryngii, suggesting that low molecular weight of these enzymes may be present due to the fact that they are constituted by two catalytic domains instead of three (Nakamura and Go 2005).

The supernatants containing laccase activity produced by P. sajor caju reached a half-life higher that $21 \mathrm{~h}$ at 30 and $40^{\circ} \mathrm{C}$, which could be very important for production in bioreactors without the necessity of refrigeration. In addition, it is important to know the enzymatic stability to estimate the replacement time of the enzymatic process.

Generally, fungal laccases have higher activity at more acidic $\mathrm{pH}$ levels and the optimal temperature may vary between 50 and $60{ }^{\circ} \mathrm{C}$ (Baldrian 2006). Copper increased the range of temperature optimal activity and allowed to improve the stability as a function of $\mathrm{pH}$ and temperature in the presence of both 0.5 or $1 \mathrm{mM}$ concentrations. These changes may be due to modifications of the enzymatic structure due to changes in glycosylation patterns (Xiao et al. 2006). It is known that the pattern of glycosylation affects the stability of laccase in basidiomycetes (Maestre-Reyna et al. 2015). In studies conducted on eukaryotic cells, metals such as copper have been added to cell culture media and were all shown to alter the glycosylation levels of diverse proteins in unique cell lines (Yuk et al. 2015). The carbohydrate portion of laccase ensures the conformational stability of the protein part and protects the enzyme from proteolysis and inactivation by radicals (Morozova et al. 2007).

The role of laccases in the degradation of lignin in nature has been extensively reported (Fonseca et al. 2010). These lignin-degrading enzymes are directly involved not only in the degradation of lignin in their natural lignocellulosic substrates but also in the degradation of various xenobiotic compounds, including dye (Gulzar et al. 2017) and recalcitrant compounds found in effluents, helping thus the tolerance and survival of fungus in hostile environments. In this sense, $P$. sajor-caju could be ranked as promising polychlorinated biphenyls degraders of chlorinated organic pollutants (Sadañoski et al. 2018).

This work demonstrated that $P$. sajor-caju may grow with effluents from the citrus industry up to a concentration of $25 \%$, and also that it is possible to detect laccase activity, which could have helped in the degradation of toxic compounds. Moreover, it provided evidence of the existence of an isoenzyme of low molecular weight $(35 \mathrm{kDa})$ induced by the presence of the citrus industry effluent in solid medium.

The inhibitory effects observed at higher concentrations could be due to the toxic nature of the effluent. Recalcitrant compounds and growth inhibitors 
liberated during the extraction process, such as fungicides, disinfectants and terpenes, may be interfering with mycelial growth.

\section{CONCLUSIONS}

The presence of copper induced significant changes in laccase concentrations, allowing to obtain the highest levels of activity 10 days after incubation with a concentration of $0.5 \mathrm{mM}$, which showed an inhibitory effect on the growth of $P$. sajor-caju, being more accentuated at higher concentrations. Laccases in cell-free extracts from the culture with added copper, showed more stability for longer periods with changes of temperature than those without copper, and also high stability with different $\mathrm{pH}$ both in the absence and presence of copper.

The optimum temperature for laccase activity increases from 50 to $60{ }^{\circ} \mathrm{C}$ due to the copper effect, while the optimal $\mathrm{pH}$ was 5 in all the experiments.

On days 5 and 7 of culture, it was possible to observe an enzyme with greater mobility $(35 \mathrm{kDa})$, while at 10 and 14 days of incubation two isoenzymes of 65 and $35 \mathrm{kDa}$ were observed in all conditions. Moreover, the enzyme of low molecular weight was induced by the presence of the effluent in solid medium.

P. sajor-caju had the ability to grow on effluents from the citrus industry, demonstrating tolerance and a potential for waste treatment, constituting a possible alternative to biodegrade and reduce the contaminating impact of effluents.

\section{ACKNOWLEDGMENTS}

This work was partially funded by the Secretaría de Ciencia y Tecnología of the Universidad Nacional de Misiones, through project 16Q660, and the Agencia Nacional de Promoción Científica y Tecnológica (PICT 2014/2051 and PICT 2017/1697).

MIF and PDZ are career members of researchers from CONICET (Argentina); MAM, SFB, JEV have fellowships for doctoral studies from CONICET and MAS has a postdoctoral fellowship from CONICET.

\section{REFERENCES}

Balcázar-López E., Méndez-Lorenzo L.H., Batista-García R.A., Esquivel-Naranjo U., Ayala M., Kumar V.V., Savary O., Cabana H., Herrera-Estrella A. and Folch-
Mallol J.L. (2016). Xenobiotic compounds degradation by heterologous expression of a Trametes sanguineus laccase in Trichoderma atroviride. PLoS ONE 11 (2), 1-3. DOI: 10.1371/journal.pone.0147997

Baldrian P. (2006). Fungal laccases - occurrence and properties. FEMS Microbiol. Rev. 30 (2), 215-42. DOI: $10.1111 / \mathrm{j} .1574-4976.2005 .00010 . \mathrm{x}$

Barr D.P. and Aust S.D. (1994). Mechanisms white rot fungi use to degrade pollutants. Environ. Sci. Technol. 28 (2), 78-87. DOI: 10.1021/es00051a002

Bevilacqua A., Cibelli F., Raimondo M.L., Carlucci A., Lops F., Sinigaglia M. and Corbo M.R. (2016). Fungal bioremediation of olive mill wastewater: using a multistep approach to model inhibition or stimulation. J. Sci. Food Agric. 97 (2), 461-468. DOI: 10.1002/jsfa.7747

Bradford M.M. (1982). A rapid and sensitive method for the quantification of microgram quantities of protein utilizing the principle of protein-dye binding. Anal. Biochem. 72 (1-2), 248-254. DOI: 10.1016/0003-2697(76)90527-3

Buddolla V.B.R., Avilala J., Arthala P.K. and Golla N. (2014). Fungal laccases and their applications in bioremediation. Enzyme Res. 163242.

DOI: $10.1155 / 2014 / 163242$

Collins P.J. and Dobson A. (1997). Regulation of laccase gene transcription in Trametes versicolor. Appl. Environ. Microbiol. 63 (9), 3444-50.

DOI: 10.1128/aem.63.9.3444-3450.1997

Dantigny P., Nanguy S.P.M., Judet-Correia D. and Bensoussan M. (2011). A new model for germination of fungi. Int. J. Food Microbiol. 146 (2), 176-181.

DOI: 10.1016/j.ijfoodmicro.2011.02.022

Di Rienzo J.A., Casanoves F., Balzarini M.G., González L., Tablada M. and Robledo C.W. (2016). InfoStat versión 2016. Grupo InfoStat, FCA, Universidad Nacional de Córdoba, Argentina [online]. http://www.infostat. com.ar 12/03/19

Field J.A., Jong E., Feijoo-Costa G. and Bont J.A.M. (1993). Screening for ligninolytic fungi applicable to the biodegradation of xenobiotics. Trends Biotechnol. 11 (2), 44-49. DOI: 10.1016/0167-7799(93)90121-O

Fonseca M.I., Shimizu E., Villalba L.L. and Zapata P.D. (2010). Copper inducing effect on laccase production of white rot fungi native from Misiones (Argentina). Enzyme Microb. Technol. 46 (6), 534-539.

DOI: 10.1016/j.enzmictec.2009.12.017

Fonseca M.I., Fariña J.I., Sanabria N.I., Villalba L.L. and Zapata P.D. (2013). Influence of culture conditions on laccase production, growth, and isoenzymes patterns in native white rot fungi from the Misiones rainforest (Argentina). BioResources 8 (2), 2855-2866.

DOI: 10.15376/biores.8.2.2855-2866

Fonseca M.I., Fariña J.I., Castrillo M.L., Rodríguez D., 
Nuñez C., Villalba L.L. and Zapata P.D. (2014a). Biopulping of wood chips with Phlebia brevispora BAFC 633 reduces lignin content and improves pulp quality. Int. Biodeterior. Biodegradation 90, 29-35. DOI: 10.1016/j.ibiod.2013.11.018

Fonseca M.I., Ramos Hryb A.B., Fariña J.I., Afanasiuk S.S., Villalba L.L. and Zapata P.D. (2014b) Effect of chemical and metallic compounds on biomass, mRNA levels and laccase activity of Phlebia brevispora BAFC 633. World J. Microbiol. Biotechnol. 30 (8), 22512262. DOI: $10.1007 / \mathrm{s} 11274-014-1646-8$

Fonseca M.I., Zapata P.D., Villalba L.L. and Fariña J.I. (2015). Characterization of the oxidative enzyme potential in wild white rot fungi from Misiones (Argentina). Acta Biol. Colomb. 20 (1), 47-56.

DOI: 10.15446/abc.v20n1.38322

Giardina P., Faraco V., Pezzella C., Piscitelli A., Vanhulle S. and Sannia G. (2010). Laccases: A never-ending story. Cell. Mol. Life Sci. 67 (3), 369-385.

DOI: 10.1007/s00018-009-0169-1

Gulzar T., Huma T., Jalal F., Iqbal S., Abrar S., Kiran S., Nosheen S., Hussain W. and Rafique M.A. (2017). Bioremediation of synthetic and industrial effluents by Aspergillus niger isolated from contaminated soil following a sequential strategy. Molecules 22 (12), 2244. DOI: $10.3390 /$ molecules 22122244

Hatakka A. (1994). Lignin-modifying enzymes from selected white-rot fungi: production and role in lignin degradation, FEMS Microbiol. Rev. 13 (2-3), 125-135. DOI: 10.1111/j.1574-6976.1994.tb00039.x

Jeon J.R., Baldrian P., Murugesan K. and Chang Y.S. (2012). Laccase catalysed oxidations of naturally occurring phenols: From in vivo biosynthetic pathways to green synthetic applications. Microb. Biotechnol. 5 (3), 318-332. DOI: 10.1111/j.1751-7915.2011.00273.x

Jones S.M. and Solomon E.I. (2015). Electron transfer and reaction mechanism of laccases. Cell Mol. Life Sci. 72 (5), 869-883. DOI: 10.1007/s00018-014-1826-6

Nakamura K. and Go N. (2005). Function and molecular evolution of multicopper blue proteins. Cell. Mol. Life Sci. 62 (18), 2050-2066.

DOI: $10.1007 / \mathrm{s} 00018-004-5076-5$

Maestre-Reyna M., Liu W.C., Jeng W.Y., Cheng-Chung L., Chih-An H., Tuan-Nan W., Wang A.H.-J. and Lie-Fen S. (2015). Structural and functional roles of glycosylation in fungal laccase from Lentinus sp. PLoS ONE 10 (4), 1-28. DOI: 10.1371/journal.pone.0120601

Moreno A.D., Ibarra D., Fernández J.L. and Ballesteros M. (2012). Different laccase detoxification strategies for ethanol production from lignocellulosic biomass by the thermotolerant yeast Kluyveromyces marxianus CECT 10875. Biores. Technol. 106, 101-109.

DOI: 10.1016/j.biortech.2011.11.108
Morozova O., Shumakovich G., Shleev S. and Yaropolov Y.I. (2007). Laccase-mediator systems and their applications: A review. Appl. Biochem. Micro. 43 (5), 523-535. DOI: 10.1134/S0003683807050055

Palanisamy S., Ramaraj S.K., Chen S.M, Thomas C. K. Yang TCK., Yi Fan P., Chen TW., Velusamy V. and Selvam S. (2017). A novel laccase biosensor based on laccase immobilized graphene-cellulose microfiber composite modified screen-printed carbon electrode for sensitive determination of catechol. Sci. Rep. 7, 41214. DOI: $10.1038 /$ srep41214

Palmieri G., Giardina P., Bianco C., Fontanella B. and Sannia G. (2000). Copper induction of laccase isoenzymes in the ligninolytic fungus Pleurotus ostreatus. Appl. Environ. Microbiol. 66 (3), 920-924. DOI: 10.1128/AEM.66.3.920-924.2000e

Patel H., Gupte A. and Gupte S. (2009). Effect of different culture conditions and inducers on production of laccase by Basidiomycetes fungal isolate Pleurotus ostreatus HP-1 under solid state fermentation. BioResources 4 (1), 268-284. DOI: 10.15376/biores.4.1.268-284

Piscitelli A., Giardina P., Lettera V., Pezzella C., Sannia G. and Faraco V. (2011). Induction and transcriptional regulation of laccases in fungi. Curr. Genomics 12 (2), 104-112. DOI: $10.2174 / 138920211795564331$

Riva S. (2006). Laccases: Blue enzymes for green chemistry. Trends Biotechnol. 24 (5), 219-226.

DOI: $10.1016 /$ j.tibtech.2006.03.006

Robinson T., Chandran B. and Nigam P. (2001). Studies on the production of enzymes by white-rot fungi for the decolourisation of textile dyes. Enzyme Microb. Technol. 29 (8), 575-579. DOI: 10.1016/S0141-0229(01)00430-6

Sadañoski M.A., Velázquez J.E., Fonseca M.I., Zapata P.D., Levin L.N. and Villalba L.L. (2018). Assessing the ability of white-rot fungi to tolerate polychlorinated biphenyls using predictive mycology. Mycology 9 (4), 239-249. DOI: $10.1080 / 21501203.2018 .1481152$

Soden D.M. and Dobson A.D.W. (2001). Differential regulation of laccase gene expression in Pleurotus sajor caju. Microbiology 147, 1755-63.

DOI: $10.1099 / 00221287-147-7-1755$

Thurston C.F. (1994). The structure and function of fungal laccases. Microbiology 140, 19-26. DOI: $10.1099 / 13500872-140-1-19$

Villalba L.L., Fonseca M.I., Giorgio M. and Zapata P.D. (2010). White rot fungi laccases for biotechnological applications. Recent. Pat. DNA Gene Seq. 4 (2), 106112. DOI: $10.2174 / 187221510793205728$

Wang H.X. and Ng T.B. (2006). Purification of a laccase from fruiting bodies of the mushroom Pleurotus eryngii. Appl. Microbiol. Biotechnol. 69 (5), 521-525. DOI: $10.1007 / \mathrm{s} 00253-005-0086-7$ 
Wesenberg D., Kyriakides I. and Agathos S.N. (2003). White-rot fungi and their enzymes for the treatment of industrial dye effluents. Biotechnol. Adv. 22 (1-2), 161-187. DOI: 10.1016/j.biotechadv.2003.08.011

Xiao Y.Z., Hong Y.Z., Li J.F., Hang J., Tong P.G., Fang W. and Zhou C.Z. (2006). Cloning of novel laccase isozyme genes from Trametes sp. AH28-2 and analyses of their differential expression. Appl. Microbiol. Biotechnol. 71 (4), 493-501.

DOI: $10.1007 / \mathrm{s} 00253-005-0188-2$
Yuk I.H., Russell S., Tang Y., Hsu W.T., Mauger J.B., Aulakh R.P., Luo J., Gawlitzek M. and Joly J.C. (2015). Effects of copper on $\mathrm{CHO}$ cells: Cellular requirements and product quality considerations. Biotechnol. Prog. 31 (1), 226-238. DOI: 10.1002/btpr.2004

Zhu C., Bao G. and Huang S. (2016). Optimization of laccase production in the white-rot fungus Pleurotus ostreatus (ACCC 52857) induced through yeast extract and copper. Biotechnol. Biotechnol. Equip. 30 (2), 270276. DOI: $10.1080 / 13102818.2015 .1135081$ 